\title{
Field workshop on the Ediacaran Corumbá Group of southwestern Brazil
}

\author{
12-16 July 2017, Corumbá, Brazil
}

\author{
Shuhai Xiao ${ }^{1 *}$, Dermeval do Carmo ${ }^{2}$, Detlef Walde ${ }^{2}$, Adalene Moreira Silva ${ }^{2}$, \\ Matheus Denezine ${ }^{2}$, and Aguinaldo Silva ${ }^{3}$ \\ ${ }^{1}$ Department of Geosciences, Virginia Polytechnic and State University, Blacksburg, VA 24061, USA; *Corresponding author, \\ E-mail:xiao@vt.edu \\ ${ }^{2}$ Instituto de Geociências, Universidade de Brasília, Brasília, DF 70910-900, Brazil \\ ${ }^{3}$ Campus Pantanal, Universidade Federal do Mato Grosso do Sul, Corumbá, MS 79304-902, Brazil
}

The Ediacaran Corumbá Group is exposed in the Corumbá region of the Paraguay belt in southwestern Brazil (D'el-Rey Silva et al., 2016) (Figs. 1 and 2). The discovery of the tubular species Corumbella werneri (Fig. 3) and Cloudina lucianoi (Fig. 4) in the Tamengo Formation of the Corumbá Group (Beurlen and Sommer, 1957; Hahn et al., 1982; Hahn and Pflug, 1985; Zaine and Fairchild, 1985) makes this unit a critical target for recent paleobiological, biostratigraphic, chemostratigraphic, and geochronological investigation (Pacheco and Leme, 2011; Spangenberg et al., 2014; Pacheco et al., 2015; Walde et al., 2015; Adôrno et al., 2017; Becker-Kerber et al., 2017). Importantly, the recently reported chemostratigraphic data and radiometric ages from the Tamengo and overlying Guaicurus formations provide key age constraints on the stratigraphic range of Corumbella werneri and Cloudina lucianoi (Boggiani et al., 2010; Parry et al., 2017). Thus, the Corumbá Group will likely play an important role in the establishment of the Terminal Ediacaran Stage (Xiao et al., 2016).

Following a successful field workshop on the Corumbá Group in 2013 (Kaufman et al., 2014), the reports of species attributed to Corumbella and Cloudina in the Bambuí and Itapucumi groups (Warren et al., 2011; Warren et al., 2014) prompted new interest in the Corumbá Group. In response to this renewed interest, Dermeval Do Carmo, Detlef Walde, Adalene Moreira Silva at University of Brasilia and Aguinaldo Silva at University of Mato Grosso do Sul organized a field workshop to examine the Corumbá Group on July 12-16, 2017. The workshop drew 16 participants from University of Brasília, University of São Paulo, Federal University of Mato Grosso do Sul, Universidade Estadual Paulista, Geopark of the Bodoquena-Pantanal, and Virginia Tech (Fig. 5).

The workshop started with seminars and focused discussion on Ediacaran stratigraphic correlation on July 11, 2017, in the Institute of Geosciences at University of Brasilia. Participants discussed the challenges in Ediacaran stratigraphic correlation and the potential importance of the Corumbá Group. On July 12, participants assembled in the city of Corumbá at the Brazil-Bolivia boundary. On the morning of July 13, participants were shown outcrops of the Tamengo Formation in Port Ladário and Pousada Pantanal, where beautifully preserved Corumbella werneri fossils are found in multiple mudstone-siltstone units; detailed stratigraphic study is ongoing to document the stratigraphic occurrence of these fossils, as well as their taphonomy and paleoenvironments. This is followed by a visit to the Sobramil Port (the type locality of the Tamengo Formation) and nearby sites where Corumbella werneri and Cloudina lucianoi were first described in the Corumbá area (Beurlen and Sommer, 1957; Hahn et al., 1982; Walde et al., 1982). These historical sites are well known to the locals, who are so proud of being associated with some of the earliest skeletonized invertebrate on Earth that several businesses bear the name Corumbella. It is not surprising that the local TV Via Morena covered this part of the field workshop in prime-time news.

On the morning of July 14, participants examined the Corumbá Group in the Laginha Mine (Votorantim Company) near the Urucum Mountain, south of Corumbá, where vase-shaped microfossils have been described from the underlying Jacadigo Group (Morais et al., 2017). At the Laginha Mine, the Corumbá Group is nearly completely exposed, including the Bocaina, Tamengo, and Guaicurus formations. Participants discussed the stratigraphic contact of these formations. Of great interest is the occurrence of at least two conglomerate intervals near the base of the Tamengo Formation, and the possible presence of a depositional break between the Tamengo and Guaicurus formations. The Guaicurus Formation at Laginha contains branching algal fossils, vendotaenids, as well as entangled filamentous structures interpreted as meiofaunal trace fossils (Parry et al., 2017). Participants also discussed the placement of the Ediacaran-Cambrian boundary and whether the Guaicurus Formation is Ediacaran or Cambrian in age.

One of the highlights of the Corumbá field workshop was a visit on the afternoon of July 14 to the Corcal Mine, where exceptionally preserved Corumbella werneri and coquinas of Cloudina lucianoi fossils occur at multiple horizons of the Tamengo Formation. Additionally, Aspidella-like discoid fossils were also discovered. Importantly, several ash beds from the Corumbá Group have been recently dated, giving tight age constraints on the fossiliferous Tamengo and Guaicurus formations (Parry et al., 2017).

On the last day of the workshop, participants were taken to the Marina Gatass Park near the Tamengo canal, where pavements are made of Tamengo Formation limestone. Astute observers were able to find Cloudina lucianoi specimens on pavement slabs. The Guaicurus Formation outcrops in the park, although it is strongly sheared and no fossils have been found. This was then followed by a trip to examine the Tamengo Formation in the Cacimba Ecopark, where the biostra- 


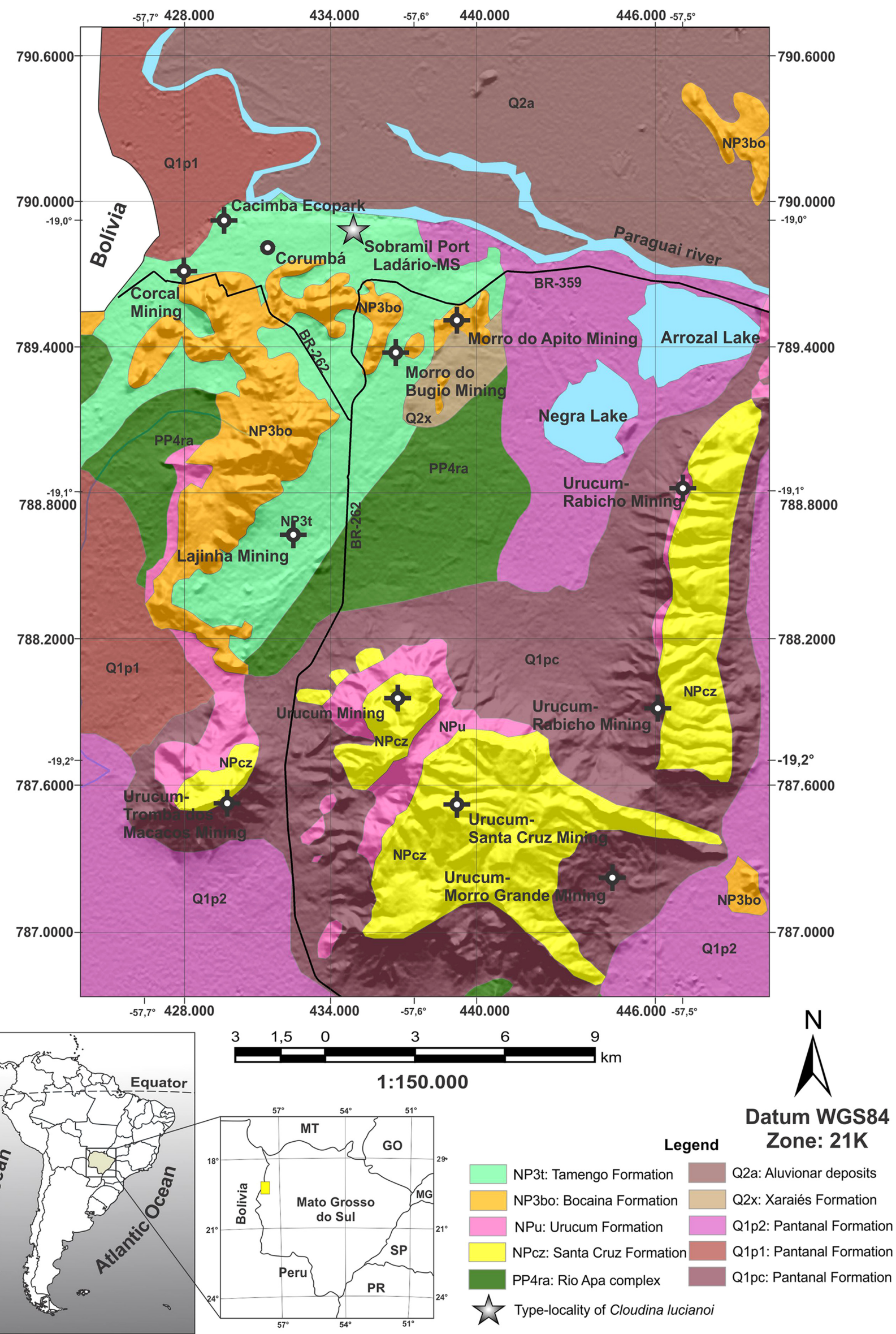

Figure 1. Geological map showing localities of the Tamengo Formation in Mato Grosso do Sul State, Brazil. 


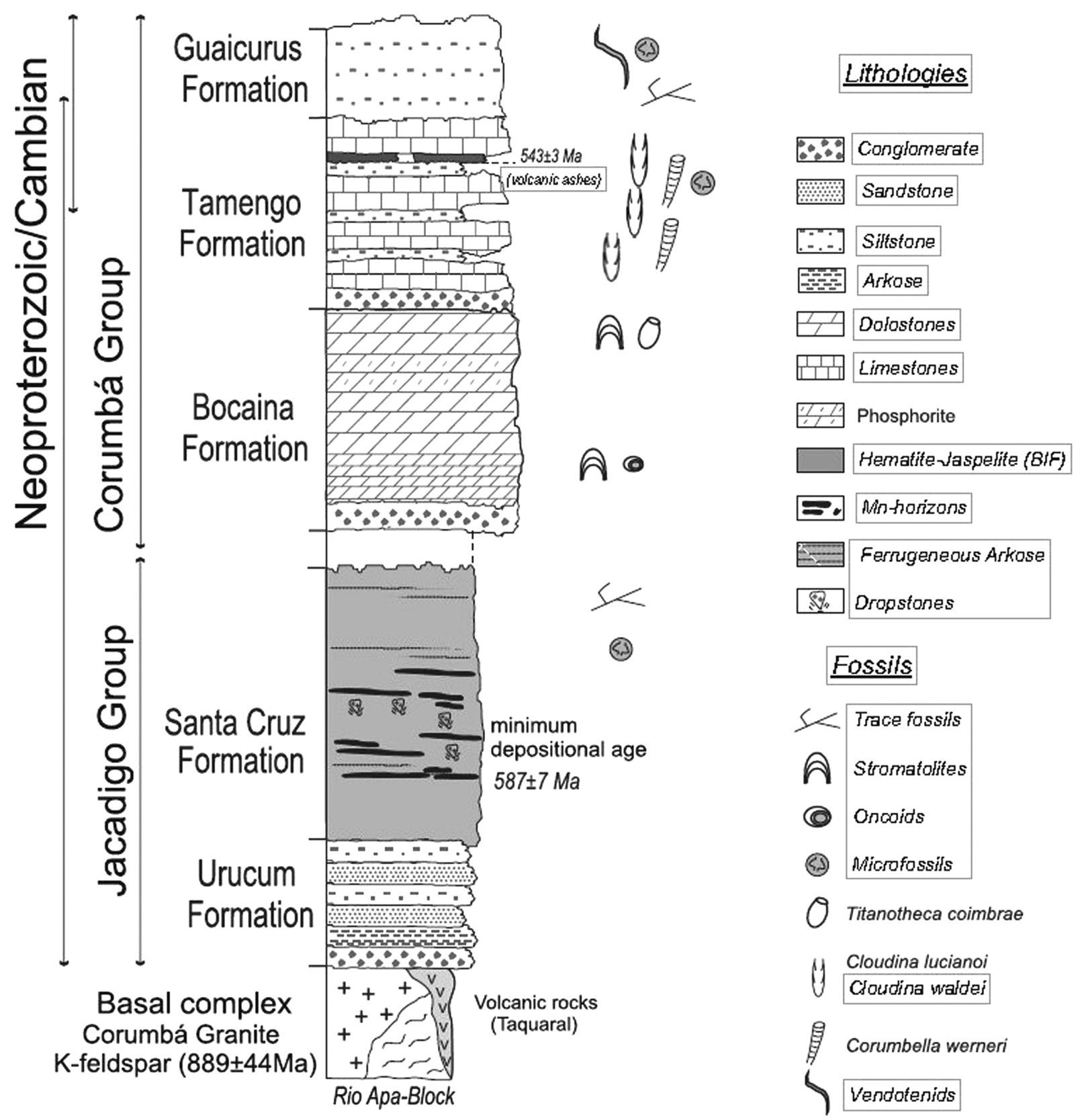

Figure 2. Neoproterozoic stratigraphic column of the Corumbá region, Mato Grosso do Sul State, Brazil (modified after Walde et al., 2015).

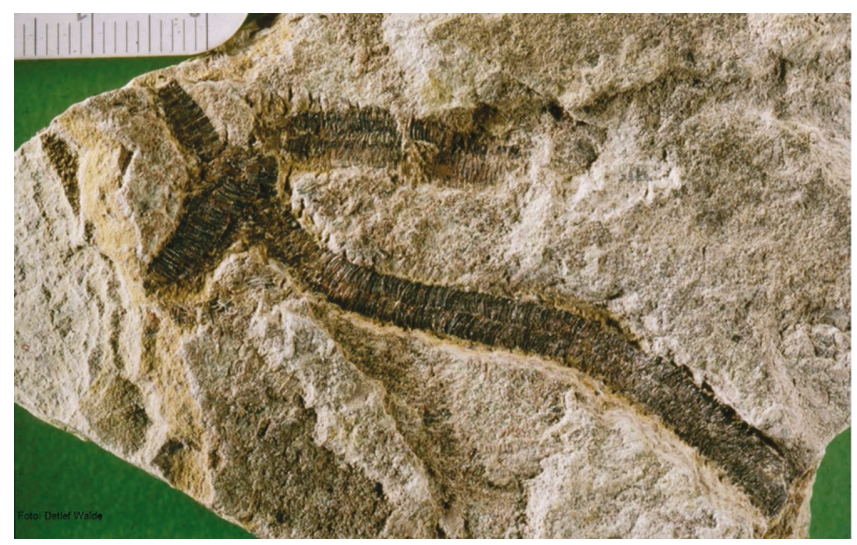

Figure 3. Corumbella werneri Hahn et al. (1982), Sobramil Port, Mato Grosso do Sul State, Brazil.
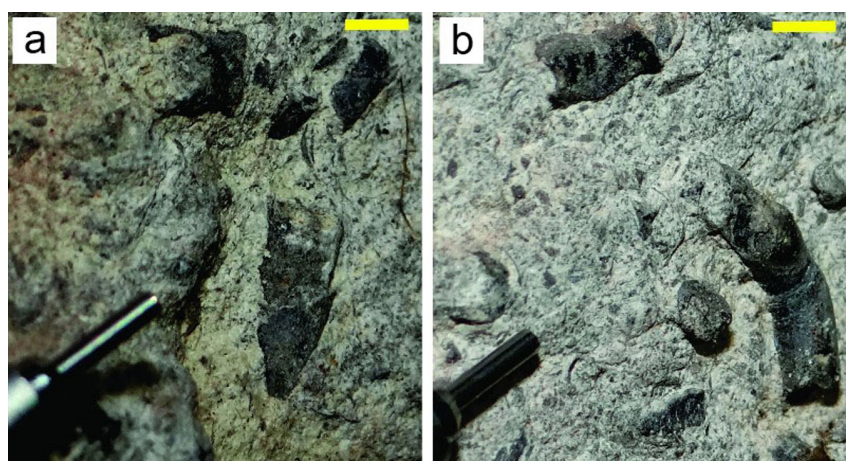

Figure 4. Cloudina lucianoi (Beurlen and Sommer, 1957), Sobramil Port, Mato Grosso do Sul State, Brazil. Photographed on a slab that is in public display at Federal University of Mato Grosso do Sul, campus Pantanal, Corumbá, Brazil. Scale bars $2.5 \mathrm{~mm}$. 


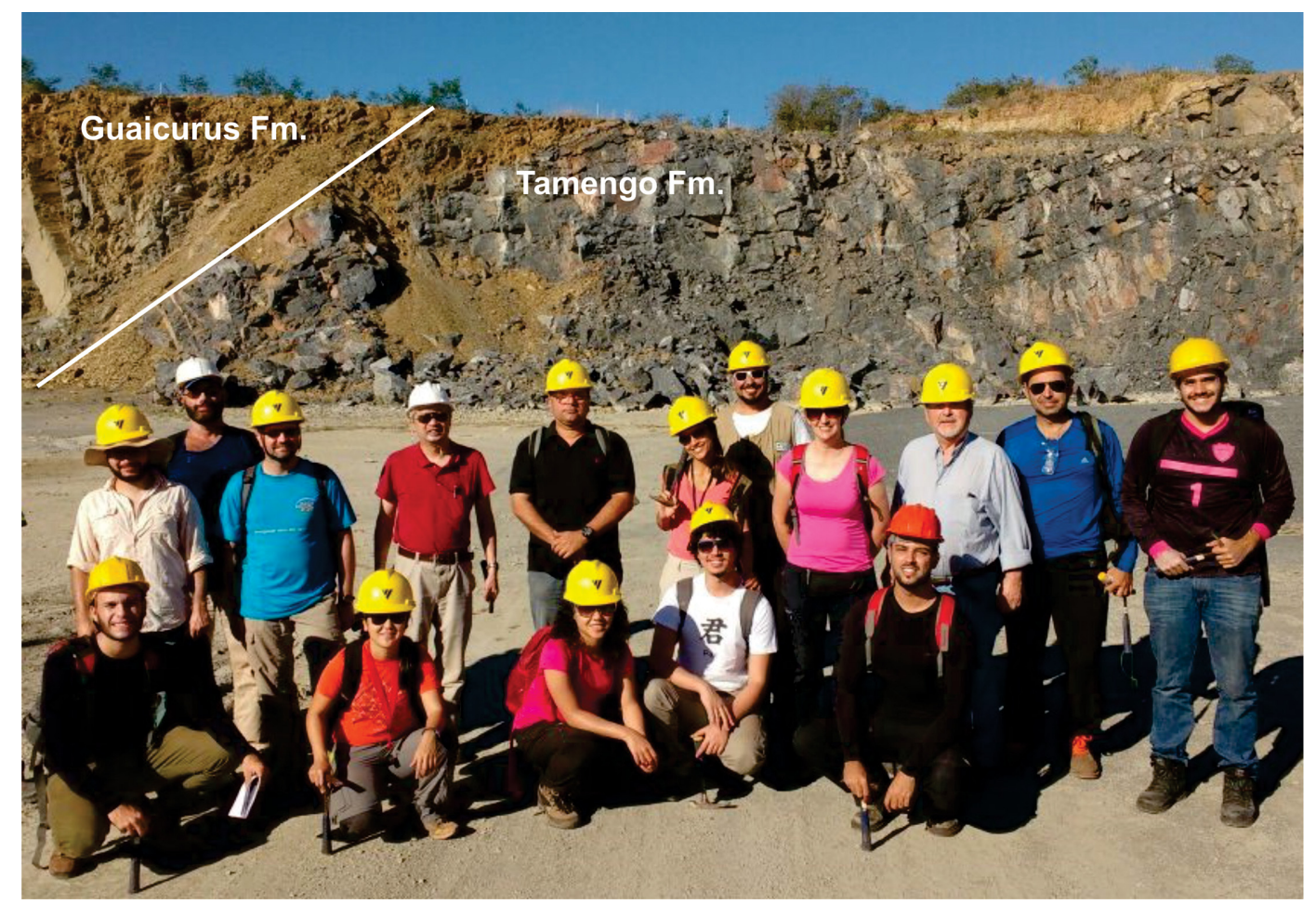

Figure 5. Group photograph of participants in the Corumbá field workshop, taken at the Laginha Mine. The Tamengo Formation limestone and Guaicurus Formation siltstone are in the background. Standing (from left to right): Gabriel Osés; Marcos Baptista; Martino Giorgioni; Shuhai Xiao; Aguinaldo Silva; Luana Morais; Anderson Palmeira; Juliana Leme; Detlef Walde; Dermeval Carmo; Livio Gonçalves. Squatting (from left to right): Arthur Reis; Juliana Okubo; Ana Luisa Porto; Cléber Diniz; Matheus Denezine.

tigraphy and chemostratigraphy of this unit was reviewed. The Corumbá field workshop was wrapped up with a tour to observe wildlife in the Pantanal.

Following the 2016 field workshop in Namibia and the 2017 field workshop in Newfoundland, Canada, the Corumbá field workshop is part of a series of activities sponsored by the Subcommission of Ediacaran Stratigraphy. The main objectives of the Subcommission is, through events such as the Corumbá field workshop, to facilitate international collaboration in the research on Ediacaran stratigraphy, to search for criteria for the subdivision and correlation of Ediacaran strata, and to define Ediacaran series and stages.

The organizers of the Corumbá field workshop would like to acknowledge financial support from the CNPq, the Brazilian Research Council, FUNDECT Research Foundation of the Mato Grosso do Sul State, University of Brasília (UnB), Federal University of Mato Grosso do Sul UFMS, Vetorial Minning (Vetorial Mineração), GEMAP/CEMAP/ UEMS, Geopark Bodoquena-Pantanal, International Commission on Stratigraphy, and NASA Exobiology and Evolutionary Biology Program.

\section{References}

Adôrno, R.R., Do Carmo, D.A., Germs, G., Walde, D.H.G., Denezine, M., Boggiani, P.C., Sousa E Silva, S.C., Vasconcelos, J.R., Tobias, T.C., Guimarães, E.M., Vieira, L.C., Figueiredo, M.F., Moraes, R., Caminha, S.A., Suarez, P.A.Z., Rodrigues, C.V., Caixeta, G.M., Pinho, D., Schneider, G., and Muyamba, R., 2017, Cloudina lucianoi (Beurlen \& Sommer, 1957), Tamengo Formation, Ediacaran, Brazil: taxonomy, analysis of stratigraphic distribution and biostratigraphy. Precambrian Research, v. 301, pp. 19-35.

Becker-Kerber, B., Pacheco, M.L.A.F., Rudnitzki, I.D., Galante, D., Rodrigues, F., and Leme, J.d.M., 2017, Ecological interactions in Cloudina from the Ediacaran of Brazil: implications for the rise of animal biomineralization. Scientific Reports, v. 7, pp. 5482.

Beurlen, K., and Sommer, F.W., 1957, Observações estratigráficas e paleontológicas sôbre o calcário Corumbá. Boletim Divisão Geologia e Mineralogia/DNPM, v. 168, pp. 1-47.

Boggiani, P.C., Gaucher, C., Sial, A.N., Babinski, M., Simon, C.M., Riccomini, C., Ferreira, V.P., and Fairchild, T.R., 2010, Chemostratigraphy of the Tamengo Formation (Corumbá Group, Brazil): a contribution to the calibration of the Ediacaran carbon-isotope curve. Precambrian Research, v. 182, pp. 382-401.

D'el-Rey Silva, L.J.H., Walde, D.H.-G., and Saldanha, D.O., 2016, The Neoproterozoic-Cambrian Paraguay Belt, central Brazil: Part I - New structural data and a new approach on the regional implications. Tectonophysics, v. 676, pp. $20-41$.

Hahn, G., Hahn, R., Leonardos, O.H., Pflug, H.D., and Walde, D.H.G., 1982, Körperlich erhaltene Scyphozoen-Reste aus dem Jungpräkambrium Brasiliens. Geologica et Palaeontologica, v. 16, pp. 1-18.

Hahn, G., and Pflug, H.D., 1985, Die Cloudinidae n. fam., Kalk-Rohren aus dem Vendium und Unter-Kambrium. Senckenbergiana Lethaea, v. 56, pp. 413-431.

Kaufman, A.J., Vickers-Rich, P., Walde, D., Gaucher, C., and Boggiani, P.C., 2014, Corumba Meeting 2013: The Neoproterozoic Paraguay Fold Belt (Brazil): glaciation, iron-manganese formation and biota. IGCP workshop and field excursion on the Ediacaran System. Episodes, v. 37, pp. 71-73.

Morais, L., Fairchild, T.R., Lahr, D.J.G., Rudnitzki, I.D., Schopf, J.W., Garcia, A.K., Kudryavtsev, A.B., and Romero, G.R., 2017, Carbonaceous and siliceous Neoproterozoic vase-shaped microfossils (Urucum 
Formation, Brazil) and the question of early protistan biomineralization. Journal of Paleontology, v. 91, pp. 393-406.

Pacheco, M.L.A.F., Galante, D., Rodrigues, F., Leme, J.d.M., Bidola, P., Hagadorn, W., Stockmar, M., Herzen, J., Rudnitzki, I.D., Pfeiffer, F., and Marques, A.C., 2015, Insights into the skeletonization, lifestyle, and affinity of the unusual Ediacaran fossil Corumbella. PLoS One, v. 10, e0114219. doi:0114210.0111371/journal.pone.0114219

Pacheco, M.L.A.F., and Leme, J., 2011, Taphonomic analysis and geometric modelling for the reconstitution of the Ediacaran metazoan Corumbella werneri Hahn et al. 1982 (Tamengo Formation, Corumbá Basin, Brazil). Journal of Taphonomy, v. 9, pp. 269-283.

Parry, L., Boggiani, P.C., Condon, D., Garwood, R., Leme, J.M., Mcllroy, D., Brasier, M.D., Trindade, R., Campanha, G.A.C., Pacheco, M.L.A.F., Diniz, C.Q.C., and Liu, A.G., 2017, Ichnological evidence for meiofaunal bilaterians from the terminal Ediacaran and earliest Cambrian of Brazil. Nature Ecology \& Evolution, v. 1, pp. 1455-1464. doi:10.1038/ s41559-017-0301-9

Spangenberg, J.E., Bagnoud-Velásquez, M., Boggiani, P.C., and Gaucher, C., 2014, Redox variations and bioproductivity in the Ediacaran: evidence from inorganic and organic geochemistry of the Corumbá Group, Brazil. Gondwana Research, v. 26, pp. 1186-1207.

Walde, D.H.G., do Carmo, D.A., Guimarães, E.M., Vieira, L.C., Erdtmann,
B.-D., Sanchez, E.A.M., Adorno, R.R., and Tobias, T.C., 2015, New aspects of Neoproterozoic-Cambrian transition in the Corumbá region (state of Mato Grosso do Sul, Brazil). Annales de Paléontologie, v. 101, pp. 213-224.

Walde, D.H.G., Leonardos, O.H., Hahn, G., and Pflug, H.D., 1982, The first Pre-Cambrian megafossils from South America, Corumbella werneri. Anais da Academia Brasileira de Ciências, v. 54, pp. 461.

Warren, L.V., Fairchild, T.R., Gaucher, C., Boggiani, P.C., Poiré, D.G., Anelli, L.E., and Inchausti, J.C.G., 2011, Corumbella and in situ Cloudina in association with thrombolites in the Ediacaran Itapucumi Group, Paraguay. Terra Nova, v. 23, pp. 382-389.

Warren, L.V., Quaglio, F., Riccomini, C., Simões, M.G., Poiré, D.G., Strikis, N.M., Anelli, L.E., and Strikis, P.C., 2014, The puzzle assembled: Ediacaran guide fossil Cloudina reveals an old proto-Gondwana seaway. Geology, v. 42, pp. 391-394.

Xiao, S., Narbonne, G.M., Zhou, C., Laflamme, M., Grazhdankin, D.V., Moczydłowska-Vidal, M., and Cui, H., 2016, Toward an Ediacaran time scale: problems, protocols, and prospects. Episodes, v. 39,pp. 540-555.

Zaine, M.F., and Fairchild, T.R., 1985, Comparison of Aulophycus lucianoi Beurlen \& Sommer from Ladário (MS) and the genus Cloudina Germs, Ediacaran of Namibia. Anais Academia Brasileira de Ciências, v. 57, pp. 130. 